\title{
Industrial Marketing Research. A Bibliometric Analysis (1990-2015)
}

\section{Introduction}

Marketing has become a phenomenon that has changed company core philosophies and modified core strategies into generating value for clients, increasingly demanded in both the consumer market and in the industrial sector. However, what differentiates massive consumer marketing from the marketing developed to exchange of goods and services between organizations? The answer lies in Business-to-Business (B2B) marketing, a concept that addresses commercial relations between industrial customers and was defined by Raymond (1991) as "the marketing of goods and services to commercial businesses, governments and other institutions that are non-profit, for use of property and services that these organizations, in turn, produce to resell to other industrial customers".

Even though the development of marketing in the B2B sector originated thousands of years ago when organizations began to emerge (LaPlaca, 1997; 2009), the incorporation of marketing theory dates back to the 1890 s and more so the most relevant contributions to this discipline were achieved in the course of the last thirty years (Hadjikhani \& LaPlaca, 2013). Even though, marketing has been well present in the business world since the beginning of time, it took several centuries before trade relations between companies became a focus of interest within the scientific research arena (Carratu, 1987; Sheth, Gardner, \& Garrett, 1988). Despite the significant progress together with the theoretical development of Industrial Marketing, it still shows a low representation of scientific research in Marketing, (LaPlaca and Katrichis, 2009).

The contributions to behavioral science in $\mathrm{B} 2 \mathrm{~B}$ has transformed the way we think about B2B Marketing, allowing us to apply the theory of Marketing to an increasing variety of purchasing situations between organizations (Hadjikhani \& LaPlaca, 2013). From this evolution, the need to measure progress in the theoretical development of this sub-discipline has arisen, considering its 
path through the review of various contributions from scientific journals, authors and universities. This paper presents these contributions by means of rankings transforming them into pivotal tools for both organizations and for the professionals that work in the field of Marketing as a whole. The main aim of this study is to provide an overview of the productivity and the influence that bring the most important countries and universities to Industrial Marketing Research. The object is to develop rankings on relevant performance within the field through the implementation of a Bibliometric methodology. This study explores the analysis of Marketing B2B obtained from Web of Science (WoS) during the periods 1990 till 2015.

It is worth mentioning that the main limitation of the study lies within the process of classifying the information since the source originates from WoS. Moreover, in order to provide a comprehensive scenario, other factors could have potentially been considered such as the editor's commitment to leading journals as well as to partnerships and conferences. The aim of this study is to examine the current information found in WoS, related to B2B Marketing research, although critical information has been omitted due to the fact that it is not included in this specific database.

\section{Theoretical Framework}

The statistical analysis on the scientific literature can be traced back to almost 50 years ago before the term bibliometric was even introduced (Glänzel, 2003). Research conducted by Pritchard (1969) explains extensively the application of mathematics and statistics to books as well other media methods and subsequently introduces the term bibliometric. Further authors address it as the discipline that studies the quantitative bibliometric materials or, as the quantitative study of the physical units published or bibliographic units (Broadus, 1987).

This type of analysis is often applied in literature in order to present a wider range picture of the research field which has increased significantly over the past years due to the rapid spread of computers and internet (Bonilla, Merigó and Torres-Abad, 2015). Note that JBIM recently published a bibliometric study of the publications of the journal in order to celebrate the 30th anniversary (Valenzuela-Fernandez et al. 2017). This paper focused on the publications of JBIM. In our paper, we are looking to the general field of B2B by analyzing all the publications of B2B in any journal. 
Obviously, JBIM is one of the leading journals in B2B and therefore, some of its publications also appear in our study. But the results and interpretations strongly differ to those of ValenzuelaFernandez et al. (2017).

Bibliometric studies are useful for many purposes; it incorporates an overview of a certain research field as well as the analysis of main investigators (Bjork, 2014; Cancino et al. 2017). It maps an overview of a determined research field according to a wide range of indicators. There are numerous techniques applied to classify the material within a bibliometric analysis (Laengle et al. 2017). The most common approach incorporates the total number of elements or the total number of citations (Cancino, Merigó, and Coronado, 2017). An alternative and certainly valuable indicator is the h-index (Hirsch, 2005). The strength of the h-index lies upon the evaluation of two substitution measurements; the total number of research conducted (determined as the number of publications) and quality (determined as the number of citations in publications) on a single number (Sharma et al. 2013). Henceforth, it is a suitable indicator for measuring the quality of influence within a group of articles.

One of the main advantages of bibliometric analysis is that it allows a specific field of research to be studied taking into account the papers, journals, authors, institutions and countries. Consequently, it is possible to develop an overview on the state in which a technique in certain fields of research is performing by examining their work and investigation as well as the most influential places where the research has been conducted (Zurita et al. 2016). In brief, it is possible to build a global picture or map of a certain field of research.

\section{Methodology}

It is of utmost importance to determine the methods and tools that will be implemented when wanting to analyze information. In order to be as informative and neutral with the information investigated as possible, the search process applied during this study has been based on the results extracted from the WoS databases belonging to Thomson and Reuters. This paper focused on the Web of Science Core Collection, which considers several sub databases, including the Conference Proceedings Citation Index. Scientific research have been included in WoS, it is a well- 
known database and incorporates all the information with more than 15,000 journals and 50 million documents. The information has been classified in 251 categories or topics and 151 areas of investigation. It is noted that there are other databases that have been considered for this study, including SCOPUS and Google Scholar, and also some software (Van Eck and Waltman, 2010). However, for the purpose of this investigation, the study solely focuses on the WoS database. There are different ways to classify the material for a bibliometric analysis. The most common indicator is the total number of articles or the total number of citations. Another useful indicator is the h-index (Hirsch, 2005), which combines the articles with cited quotes and the number of studies that have received one or more citations. This study works with several indicators to provide a comprehensive view of the sets of articles. One of these indicators categorizes the information. Conversely, the others are also included in the analysis so that the reader can have a general idea on who is conducting the investigation through a set of different indicators (Merigó et al. 2015a; 2016). It should be noted that the general assumption is that the number of articles show that productivity and the number of citations reflect an influence upon a group of articles (Merigó et al. 2015b).

When performing a bibliometric analysis, several limitations may arise due to the specific nature of the research conducted. Firstly, the database always provides a unit for each journal, author, university or country involved in the article. Nonetheless, some studies may have an author, while others may have three or four. Additionally, the unit given in the first case has the same value as in the second. Nevertheless, today WoS is not taking this matter into consideration. A second limitation emphasizes upon the value of magazines and that its publication in the above section of newspapers differs from publications in the middle range of newspapers. A third limitation is that numerous studies can potentially obtain a better bibliometric evaluation, due to the type of research and citations received as well as other related work. Similarly, many essential studies can receive quotes due to the simple fact that not so many scientists are working on this topic or research field. Ultimately, multiple and important problems within scientific research cannot be evaluated with bibliometric measurements; including participation in international journals and conferences. 


\section{Results}

The results of this study provide six important insights on B2B marketing research:

(1) The analysis emerging from the most influential and productive countries working on B2B Marketing, take into consideration the exclusivity of working with the Web of Science (WoS) database.

(2) The Examination of over five-year and three-year periods of countries that have been publishing on Marketing B2B from 1990 till 2015.

(3) The study of cross and self-citations among the most important countries (4). A study on the most influential as well as productive universities that have worked on investigations related to B2B.

(4) The analysis of five-year and three-year periods of the universities that have published the moss on Marketing B2B from 1990 till 2015.

(5) The study of cross and self-citation among the most influential universities.

(6) The study developing VOS graphics, taking into consideration both variables.

\section{Most influential countries in Marketing B2B research between 1990-2015}

It is of utmost importance to assess the progress attained within the investigation of Industrial Marketing, the power to understand and analyze the influence each country has on the development of scientific literature in this particular discipline. According to information provided by the Web of Science, the term countries indicate the number of publications made by institutions that belong to a particular country. It is worth mentioning that authors from other countries can publish articles under the name of a country while working in institutions that are found in that country. Table I presents a ranking of the 30 most productive and influential countries in this field, which was ordained under the criteria of the h-index in the first instance, after considering the total number of publications. 
As observed in Table I, the United States is clearly the most productive and influential country in the world. The number of publications in this country substantially exceeds the runner up, the United Kingdom, in terms of number of citations. From the total number of publications considered for this ranking, the US has made more than $30 \%$ of publications.

\section{Analysis of five-year and three-year periods of the most influential countries in Marketing B2B dated from 1990 till 2015}

In order to analyze the evolution in scientific contribution to the study on B2B Marketing, the following tables show the contribution of the most important countries in this field of research from 1990 till 2015, separated into five-year periods and three-year periods. Each period is made up of 20 countries and was re-ordered according to the total number of publications, in order to provide a clearer scenario with respect to progress in productivity of the countries that are listed, see Table II.

Insert Table II about here

Insert Table III about here

As reflected throughout Table III, the US and UK have maintained their leadership over the past years, and the difference between the number of publications in the first place and other countries has decreased over time, which shows that the interest in B2B Marketing as a focus of scientific research has increased globally. Generally, the total number of publications by the countries considered in each five-year period increased significantly from 281 publications in the first half of the five-year period, to 1089 in the last three years, that is to say, almost 4 times the productivity. 


\section{Cross-analysis and self-citation among the most important countries on Marketing B2B}

The following Table IV shows the cross-citation as well as self-citation among countries with the highest number of publications, providing greater perspective on the role that the top ranked countries have in the framework of research in Marketing B2B.

Insert Table IV about here

The most influential universities in Marketing B2B from 1990 till 2015

Universities as a whole play a key role in the generation, propulsion and dissemination of knowledge. For this reason, it is important to focus on the following analysis of this variable to know the progress in scientific research on B2B Marketing and account for how the most important universities worldwide have increased their interest in this discipline and have contributed to its theoretical development over time.

Subsequently, this analysis focuses on the most influential institutions. Table $V$ shows the ranking of the 30 universities with the highest number of citations in Marketing B2B, sorted according to their $\mathrm{H}$-index and considering other variables such as total number of publications, number of total citations and the number of average citations per publication.

Insert Table $\mathrm{V}$ about here

The analysis in five-year periods and three-year periods of the most influential universities in B2B Marketing from 1990 till 2015

In order to analyze the evolution in the scientific contribution to the study of B2B Marketing, the following tables show the contribution of the most important countries in this field of research during the period from 1990 till 2015, separated into five-year periods (Table VI) and three-year periods (Table VII). Each period is made up of 20 countries and has been ordered according to the total number of publications, in order to provide a clearer scenario with respect to progress in productivity in the countries in the listings 
Insert Table VI about here

Insert Table VII about here

The previous tables indicate the evolution of over five-year periods and three-year periods of publications from notorious universities. In relation to the previous ranking, we see that the majority come from the US and UK, which is consistent with the fact that they are the most influential countries in this area. Listings vary over time; however, you can highlight the universities of Michigan, Georgia and Manchester for outstanding contributions and its impact is reflected in the overall ranking. The following Table VIII summarizes the frequency with which the most important universities have with cross citations and auto-citations.

Insert Table VIII about here

\section{Country and most influential universities mapping through the application of VOS viewer software}

The VOS Viewer software (Van Eck and Waltman, 2010) is a program for the construction and visualization of bibliometric networks in terms of bibliographic coupling, co - citation and co authorship. Bibliographic coupling (Bibliographic Coupling) occurs when two different articles cite a third common study in their reference lists (Kessler, 1963). Throughout this study, bibliographic coupling between the countries that have made greater number of influential publications on B2B Marketing during the past 26 years have been analyzed, such as in the case of universities who have excelled in specific work. Figure 1 shows the bibliographic coupling between countries using VOS viewer.

Insert Figure 1 about here 
Consistent with what has been previously presented by means of global and five-year rankings, the United States has the largest network of bibliographic coupling, which is consistent with previous results, since it is the most productive and influential country in scientific research on Marketing B2B since its inception.

Figure 2 takes us back to the item of the universities that have had the greatest impact on the field, using the same tool.

Insert Figure 2 about here

It can be observed that in accordance to the list of Universities shown above, the University of Michigan, whose $\mathrm{H}$-index is the highest in the ranking as well as Georgia State University, has the highest number of publications are highlighted.

\section{Conclusions}

This article provides an overview of bibliometric research conducted between the periods starting in 1990 till 2015 in B2B Marketing. The focus of this study is to determine the most productive and influential universities in relation to this matter for the scientific community, through a ranking compiled from information found on the Web of Science (WoS).

The results show a robust surge in B2B Marketing research since its inception, which is aligned with the growth of scientific marketing as a whole. This study presents an analysis of the thirty countries and its most influential universities within the field studied, taking into consideration upon a series of indicators that provide a more comprehensive picture regarding the relevant performers within research development in Industrial Marketing.

From both rankings, the presence of the US as the birthplace of a significant number of publications of impact can be highlighted, which has maintained its hegemony for the first five-year period presented in the study. This is consistent with the most influential University, the Michigan State University and the Georgia State University; both North American Universities, both have presented 
not only high productivity but also great importance in this field of research. Some other countries that perform very well in this field and according to their population size are UK, Australia, Finland, Sweden, Denmark, Norway and New Zealand. It is also worth noting that most of the countries on the list are developed countries. Note that China and India obtain remarkable results in absolute numbers if considering the wealth of the countries.

Through the analysis of the five-year and three-year periods, the results demonstrate a substantial increase in the interest that the scientific community has shown in Marketing B2B, a work that has been incorporated by more countries and universities as major performers that were not involved in the early stages. Still, in theoretical terms, B2B Marketing still requires extensive development and scope

This article seeks to provide a general notion regarding the developments in research of B2B Marketing. Taking into account other variables that were not previously considered such as universities and countries in which the transcendental contributions to this field have taken place, giving a closer look, which gives rise to further discussions and studies with more detail to the history of this science in the future.

Note that in the bibliometric and scientometric literature, there are many other indicators that could be used in order to quantify and evaluate the results (Alonso et al. 2009). The assumption of the work is that the indicators used are representative enough to provide a complete picture considering different perspectives, so the each reader may focus on the specific issues that are more interesting according to their interests. Note that the main focus of the article is to consider productivity and influence which are usually recognized as the most significant variables for measuring academic research (Merigó et al. 2015b).

\section{References}

1. Alonso, S., Cabrerizo, F. J., Herrera-Viedma, E., and Herrera, F. (2009). "H-index: A review focused on its variants, computation, and standarization for different scientific fields", Journal of Informetrics, 3, 273-289.

2. Bjork, S. O. (2014), "Time series citation data: The Nobel Prize in economics", Scientometrics, Vol.98 No. 1, pp. 185-196. 
3. Bonilla, C., Merigó, J. M., and Torres-Abad, C. (2015), "Economics in Latin America: A bibliometric analysis", Scientometrics, Vol. 105 No. 2, pp. 1239-1252.

4. Broadus, R. N. (1987), "Early approaches to bibliometrics". Journal of the American Society for Information Science, Vol. 38 No. 2, pp.127-129.

5. Cancino, C., Merigó, J. M., and Coronado, F. (2017). "Leading universities in innovation research", Journal of Innovation \& Knowledge, Vol. 2, pp. 106-124.

6. Cancino, C., Merigó, J. M., Coronado, F., Dessouky, Y. and Dessouky, M. (2017). "Forty years of Computers \& Industrial Engineering: A bibliometric analysis", Computers \& Industrial Engineering, Vol. 113, pp. 614-629.

7. Carratu, V. (1987), "Commercial counterfeiting", in Murphy, J. (Ed.), Branding: A key marketing tool, Macmillan Press Limited, London.

8. Glänzel, W. (2003), "Bibliometrics as a research field", Course Handouts, pp. 1-115.

9. Hadjikhani, A. and LaPlaca, P. (2013), "Development of B2B marketing theory", Industrial Marketing Management, Vol. 42 No. 3, pp. 294-305.

10. Hirsch, J. E. (2005), "An index to quantify an individual's scientific research output", Proceedings of the National Academy of Sciences the United States of America, Vol.102 No. 46, pp. 16569-16572.

11. Kessler, M. M. (1963). "Bibliographic coupling between scientific papers", American Documentation, Vol. 14, pp. 10-25.

12. Laengle, S., Merigó, J. M., Miranda, J., Slowinski, R., Bomze, I., Borgonovo, E., Dyson, R. G., Oliveira, J. F. and Teunter, R. (2017). "Forty years of the European Journal of Operational Research: A bibliometric overview", European Journal of Operational Research, Vol. 262 No 3, pp. 803-816.

13. LaPlaca, P. J. (1997), "Contributions to marketing theory and practice from industrial marketing management", Journal of Business Research, Vol. 38 No 3, pp. 179-198.

14. LaPlaca, P. J. (2009), "Improving B2B marketing process", Industrial Marketing Management, Vol. 38 No 3, pp. 237-238.

15. LaPlaca, P. J., and Katrichis, J. M. (2009), "Relative presence of business-to-business research in the marketing literature", Journal of Business-to-Business Marketing, Vol. 16 No 1-2, pp. 122.

16. Merigó, J. M., Rocafort, A. and Aznar-Alarcón, J. P. (2016), "A bibliometric overview of business \& economics research", Journal of Business Economics and Management, Vol. 17 No 3, pp.397-413.

17. Merigó, J. M., Gil-Lafuente, A. M., and Yager, R. R. (2015), "An overview of fuzzy research with bibliometric indicators", Applied Soft Computing, Vol. 27, pp. 420-433.

18. Merigó, J. M., Mas-Tur, A., Roig-Tierno, N., and Ribeiro-Soriano., D. (2015), "A bibliometric overview of the Journal of Business Research between 1973 and 2014", Journal of Business Research, Vol, 68 No 12, pp.2645-2653.

19. Pritchard, A. (1969), "Statistical bibliography or bibliometrics?", Journal of Documentation, Vol. 25, pp. 348-349.

20. Raymond, E. (1991), Industrial marketing cases and concepts, 4ํEdición. Prentice Hall College Div.

21. Sharma, B., Boet, S., Grantcharov, T., Shin, E., Barrowman, N. J., and Bould, M. D. (2013), "The h-index outperforms other bibliometrics in the assessment of research performance in general surgery: a province-wide study", Surgery, Vol 153 No 4, pp. 493-501.

22. Sheth, J. N., Gardner, D. M., and Garrett, D. E. (1988), Marketing theory: Evolution and evaluation. John Wiley \& Sons, Inc, New York. 
23. Valenzuela, L., Merigó, J. M., Johnston, W., Nicolás, C. \& Jaramillo, F. (2017). "Thirty years of the Journal of Business \& Industrial Marketing: A bibliometric analysis", Journal of Business \& Industrial Marketing, Vol. 32 No 1, pp. 1-18.

24. Van Eck, N. J., and Waltman, L. (2010), "Software survey: VOSviewer, a computer program for bibliometric mapping", Scientometrics, Vol. 84 No 2, pp. 523-538.

25.Zurita, G., Merigó, J. M., and Lobos-Ossandón, V. (2016), "A bibliometric analysis of highly cited articles in educational research", Proceedings of the World Congress on Engineering 2016, Vol I, WCE 2016, June-July, London, U.K. 
Table I

The 30 most influential countries in Marketing Research B2B.

\begin{tabular}{|c|c|c|c|c|c|c|c|}
\hline $\mathrm{R}$ & Country & $\mathrm{H}$ & $\mathrm{TP}$ & $\mathrm{TC}$ & $\mathrm{TC} / \mathrm{TP}$ & TP/Pop & TP/GDP \\
\hline 1 & USA & 76 & 1598 & 30234 & 18,92 & 4,90 & 28,04 \\
\hline 2 & UK & 40 & 597 & 8387 & 14,05 & 9,18 & 14,93 \\
\hline 3 & Australia & 34 & 256 & 3946 & 15,41 & 10,67 & 4,92 \\
\hline 4 & Germany & 32 & 173 & 4183 & 24,18 & 2,11 & 4,12 \\
\hline 5 & Finland & 27 & 251 & 3211 & 12,79 & 41,83 & 5,84 \\
\hline 6 & Sweden & 26 & 179 & 3165 & 17,68 & 17,90 & 3,51 \\
\hline 7 & Canada & 26 & 163 & 2680 & 16,44 & 4,53 & 3,88 \\
\hline 8 & Netherlands & 26 & 138 & 2388 & 17,30 & 8,12 & 3,07 \\
\hline 9 & France & 24 & 134 & 2262 & 16,88 & 2,00 & 3,53 \\
\hline 10 & China & 24 & 170 & 1963 & 11,55 & 0,12 & 21,25 \\
\hline 11 & Denmark & 20 & 87 & 1758 & 20,21 & 14,50 & 1,61 \\
\hline 12 & South Korea & 19 & 79 & 865 & 10,95 & 1,55 & 2,82 \\
\hline 13 & Taiwan & 18 & 151 & 1153 & 7,64 & 6,57 & 6,86 \\
\hline 14 & Belgium & 18 & 40 & 866 & 21,65 & 3,64 & 0,98 \\
\hline 15 & Spain & 17 & 101 & 950 & 9,41 & 2,20 & 3,74 \\
\hline 16 & Switzerland & 17 & 72 & 849 & 11,79 & 9,00 & 0,91 \\
\hline 17 & Italy & 16 & 87 & 754 & 8,67 & 1,45 & 2,81 \\
\hline 18 & Norway & 15 & 83 & 961 & 11,58 & 16,60 & 1,19 \\
\hline 19 & New Zealand & 15 & 65 & 926 & 14,25 & 13,00 & 1,71 \\
\hline 20 & Turkey & 14 & 29 & 418 & 14,41 & 0,36 & 2,64 \\
\hline 21 & Singapore & 13 & 34 & 729 & 21,44 & 5,67 & 0,64 \\
\hline 22 & Greece & 12 & 40 & 644 & 16,10 & 4,00 & 2,22 \\
\hline 23 & Ireland & 12 & 37 & 335 & 9,05 & 7,40 & 0,59 \\
\hline 24 & Portugal & 12 & 32 & 330 & 10,31 & 3,20 & 1,60 \\
\hline 25 & Austria & 11 & 30 & 577 & 19,23 & 3,33 & 0,68 \\
\hline 26 & Cyprus & 9 & 14 & 205 & 14,64 & 14,00 & 0,61 \\
\hline 27 & India & 8 & 31 & 379 & 12,23 & 0,02 & 15,50 \\
\hline 28 & Israel & 7 & 16 & 186 & 11,63 & 1,78 & 0,43 \\
\hline 29 & Slovenia & 7 & 21 & 148 & 7,05 & 10,50 & 1,00 \\
\hline 30 & South Africa & 6 & 17 & 197 & 11,59 & 0,30 & 3,40 \\
\hline
\end{tabular}


Table II

The 20 most influential countries sorted by five-year periods for the period between 1990 and 2009.

\begin{tabular}{|c|c|c|c|c|c|c|c|c|c|c|c|c|c|c|c|c|c|c|c|c|}
\hline \multicolumn{6}{|c|}{ 1990-1994 } & \multicolumn{5}{|c|}{ 1995-1999 } & \multicolumn{5}{|c|}{$2000-2004$} & \multicolumn{5}{|c|}{ 2005-2009 } \\
\hline $\mathrm{R}$ & Country & TP & TC & $\mathrm{H}$ & $\mathrm{TC} / \mathrm{TP}$ & Country & TP & $\mathrm{TC}$ & $\mathrm{H}$ & $\mathrm{TC} / \mathrm{TP}$ & Country & $\mathrm{TP}$ & TC & $\mathrm{H}$ & $\mathrm{TC} / \mathrm{TP}$ & Country & TP & TC & $\mathrm{H}$ & $\mathrm{TC} / \mathrm{T}$ \\
\hline 1 & USA & 207 & 2665 & 22 & 12,87 & USA & 214 & 4732 & 36 & 22,11 & USA & 297 & 12622 & 59 & 42,50 & USA & 387 & 7482 & 40 & 19,33 \\
\hline 2 & UK & 21 & 158 & 9 & 7,52 & UK & 37 & 1073 & 17 & 29,00 & UK & 78 & 2508 & 28 & 32,15 & UK & 154 & 2776 & 28 & 18,03 \\
\hline 3 & Canada & 18 & 284 & 9 & 15,78 & Canada & 20 & 546 & 15 & 27,30 & Australia & 38 & 1187 & 21 & 31,24 & Australia & 81 & 1515 & 21 & 18,70 \\
\hline 7 & Australia & 5 & 56 & 3 & 11,20 & Australia & 15 & 505 & 8 & 33,67 & Netherlands & 26 & 677 & 15 & 26,04 & Finland & 53 & 1176 & 20 & 22,19 \\
\hline 6 & Netherlands & 3 & 68 & 3 & 22,67 & Netherlands & 7 & 178 & 6 & 25,43 & Sweden & 22 & 1073 & 16 & 48,77 & Germany & 47 & 1896 & 23 & 40,34 \\
\hline 5 & Belgium & 2 & 81 & 2 & 40,50 & Germany & 7 & 190 & 5 & 27,14 & Germany & 21 & 1346 & 16 & 64,10 & Canada & 46 & 797 & 16 & 17,33 \\
\hline 4 & South Africa & 2 & 26 & 2 & 13,00 & France & 7 & 169 & 5 & 24,14 & Canada & 20 & 741 & 14 & 37,05 & Netherlands & 45 & 1104 & 20 & 24,53 \\
\hline 5 & Israel & 2 & 18 & 2 & 9,00 & Finland & 6 & 193 & 4 & 32,17 & Finland & 15 & 715 & 11 & 47,67 & Taiwan & 44 & 638 & 15 & 14,50 \\
\hline 6 & India & 2 & 8 & 2 & 4,00 & China & 5 & 278 & 5 & 55,60 & Denmark & 13 & 855 & 11 & 65,77 & China & 42 & 889 & 17 & 21,17 \\
\hline 7 & Austria & 2 & 7 & 2 & 3,50 & Sweden & 4 & 176 & 4 & 44,00 & Norway & 13 & 472 & 11 & 36,31 & France & 41 & 1132 & 19 & 27,61 \\
\hline 8 & Sweden & 2 & 577 & 1 & 288,50 & Singapore & 4 & 85 & 3 & 21,25 & China & 13 & 361 & 11 & 27,77 & Sweden & 39 & 796 & 16 & 20,41 \\
\hline 9 & Germany & 2 & 40 & 1 & 20,00 & Belgium & 3 & 70 & 3 & 23,33 & France & 12 & 493 & 9 & 41,08 & South Korea & 35 & 541 & 16 & 15,46 \\
\hline 10 & Taiwan & 2 & 16 & 1 & 8,00 & $\begin{array}{l}\text { New } \\
\text { Zealand }\end{array}$ & 3 & 11 & 3 & 3,67 & Spain & 11 & 208 & 8 & 18,91 & Spain & 32 & 486 & 12 & 15,19 \\
\hline 11 & France & 2 & 3 & 1 & 1,50 & Italy & 3 & 30 & 2 & 10,00 & Singapore & 7 & 454 & 5 & 64,86 & Italy & 28 & 438 & 13 & 15,64 \\
\hline 12 & Ireland & 1 & 50 & 1 & 50,00 & Norway & 2 & 85 & 2 & 42,50 & Austria & 6 & 301 & 6 & 50,17 & Denmark & 27 & 463 & 14 & 17,15 \\
\hline 13 & Cameroon & 1 & 18 & 1 & 18,00 & South Korea & 2 & 69 & 2 & 34,50 & Belgium & 6 & 190 & 5 & 31,67 & New Zealand & 19 & 374 & 11 & 19,68 \\
\hline 14 & Italy & 1 & 8 & 1 & 8,00 & Taiwan & 2 & 44 & 2 & 22,00 & Greece & 5 & 117 & 5 & 23,40 & Greece & 17 & 333 & 8 & 19,59 \\
\hline 15 & Hong Kong & 1 & 7 & 1 & 7,00 & Turkey & 2 & 38 & 2 & 19,00 & Ireland & 5 & 82 & 5 & 16,40 & Norway & 17 & 192 & 8 & 11,29 \\
\hline 16 & Portugal & 1 & 6 & 1 & 6,00 & Austria & 2 & 14 & 2 & 7,00 & New Zealand & 4 & 234 & 4 & 58,50 & Switzerland & 15 & 270 & 9 & 18,00 \\
\hline 17 & Norway & 1 & 4 & 1 & 4,00 & Israel & 2 & 4 & 2 & 2,00 & India & 4 & 193 & 3 & 48,25 & Belgium & 12 & 397 & 9 & 33,08 \\
\hline 18 & Spain & 1 & 2 & 1 & 2,00 & India & 2 & 10 & 1 & 5,00 & Turkey & 3 & 118 & 3 & 39,33 & Turkey & 9 & 175 & 7 & 19,44 \\
\hline 19 & Chile & 1 & 2 & 1 & 2,00 & Denmark & 1 & 180 & 1 & 180,00 & Italy & 3 & 40 & 3 & 13,33 & Ireland & 9 & 109 & 7 & 12,11 \\
\hline 20 & Poland & 1 & 1 & 1 & 1,00 & Greece & 1 & 51 & 1 & 51,00 & South Africa & 2 & 115 & 2 & 57,50 & Portugal & 9 & 148 & 6 & 16,44 \\
\hline
\end{tabular}

Abbreviations: $\mathrm{R}=$ Rank; $\mathrm{TP}=$ Total publications; $\% \mathrm{TP} /$ Total $=$ Percentage of publications of the total in art; $\mathrm{TC}=$ Total citations; $\mathrm{TC} / \mathrm{TP}=\mathrm{Citations}$ per paper, $\mathrm{H}=\mathrm{H}$-index. 
Table III

The 20 most influential countries ordered by three-year periods between 2010 and 2015.

\begin{tabular}{|c|c|c|c|c|c|c|c|c|c|c|}
\hline \multirow[b]{2}{*}{$\mathrm{R}$} & \multicolumn{5}{|c|}{$2010-2012$} & \multicolumn{5}{|c|}{$2013-2015$} \\
\hline & Country & $\mathrm{TP}$ & $\mathrm{TC}$ & $\mathrm{H}$ & $\mathrm{TC} / \mathrm{TP}$ & Country & TP & $\mathrm{TC}$ & $\mathrm{H}$ & TC/TP \\
\hline 1 & USA & 255 & 2359 & 23 & 9,25 & USA & 238 & 375 & 8 & 1,58 \\
\hline 2 & UK & 154 & 1571 & 19 & 10,20 & UK & 153 & 301 & 8 & 1,97 \\
\hline 3 & Finland & 58 & 812 & 15 & 14,00 & Finland & 119 & 315 & 10 & 2,65 \\
\hline 4 & Germany & 56 & 632 & 14 & 11,29 & Sweden & 71 & 154 & 7 & 2,17 \\
\hline 5 & Australia & 55 & 567 & 13 & 10,31 & China & 64 & 71 & 5 & 1,11 \\
\hline 6 & Taiwan & 52 & 352 & 11 & 6,77 & Australia & 62 & 116 & 6 & 1,87 \\
\hline 7 & China & 45 & 357 & 10 & 7,93 & Taiwan & 49 & 70 & 4 & 1,43 \\
\hline 8 & Sweden & 41 & 389 & 12 & 9,49 & France & 41 & 106 & 6 & 2,59 \\
\hline 9 & Netherlands & 33 & 307 & 11 & 9,30 & Germany & 40 & 80 & 5 & 2,00 \\
\hline 10 & Switzerland & 32 & 399 & 12 & 12,47 & Italy & 33 & 60 & 5 & 1,82 \\
\hline 11 & France & 31 & 359 & 11 & 11,58 & Canada & 29 & 82 & 5 & 2,83 \\
\hline 12 & Spain & 31 & 201 & 9 & 6,48 & Norway & 28 & 55 & 5 & 1,96 \\
\hline 13 & Canada & 30 & 230 & 9 & 7,67 & Spain & 26 & 53 & 5 & 2,04 \\
\hline 14 & New Zealand & 22 & 257 & 9 & 11,68 & Netherlands & 24 & 54 & 5 & 2,25 \\
\hline 15 & Denmark & 22 & 211 & 9 & 9,59 & Denmark & 24 & 49 & 4 & 2,04 \\
\hline 16 & Norway & 22 & 153 & 9 & 6,95 & Switzerland & 22 & 83 & 5 & 3,77 \\
\hline 17 & South Korea & 20 & 180 & 7 & 9,00 & South Korea & 20 & 30 & 2 & 1,50 \\
\hline 18 & Italy & 19 & 178 & 9 & 9,37 & New Zealand & 17 & 50 & 5 & 2,94 \\
\hline 19 & Brazil & 11 & 60 & 4 & 5,45 & Brazil & 15 & 15 & 2 & 1,00 \\
\hline 20 & Slovenia & 11 & 52 & 3 & 4,73 & Ireland & 14 & 17 & 2 & 1,21 \\
\hline
\end{tabular}

Abbreviations: $\mathrm{R}=$ Rank; $\mathrm{TP}=$ Total publications; \%TP/Total $=$ Percentage of publications of the total in art; TC = Total citations; TC/TP = Citations per paper, $\mathrm{H}=\mathrm{H}$-index. 
Table IV

Citing articles between countries.

\begin{tabular}{|c|c|c|c|c|c|c|c|c|c|c|c|c|c|c|c|}
\hline Country & USA & UK & Australia & Finland & Sweden & Germany & China & Canada & Taiwan & Netherlands & France & Spain & Denmark & Italy & Norway \\
\hline USA & 6140 & 1137 & 669 & 271 & 371 & 700 & 362 & 650 & 193 & 437 & 342 & 153 & 216 & 93 & 106 \\
\hline UK & 1865 & 1175 & 396 & 324 & 398 & 365 & 185 & 305 & 96 & 288 & 258 & 74 & 217 & 101 & 151 \\
\hline Australia & 918 & 323 & 361 & 118 & 122 & 159 & 78 & 131 & 46 & 110 & 97 & 42 & 93 & 25 & 56 \\
\hline Finland & 485 & 293 & 182 & 367 & 238 & 180 & 28 & 94 & 34 & 126 & 153 & 19 & 121 & 62 & 74 \\
\hline Sweden & 436 & 233 & 115 & 178 & 270 & 135 & 24 & 72 & 22 & 69 & 88 & 21 & 55 & 49 & 72 \\
\hline Germany & 855 & 259 & 153 & 85 & 101 & 373 & 61 & 128 & 22 & 152 & 78 & 22 & 68 & 30 & 27 \\
\hline China & 1335 & 359 & 213 & 103 & 112 & 150 & 429 & 125 & 120 & 126 & 73 & 63 & 60 & 33 & 40 \\
\hline Canada & 775 & 193 & 95 & 57 & 69 & 93 & 48 & 189 & 27 & 58 & 57 & 16 & 45 & 24 & 30 \\
\hline Taiwan & 1175 & 324 & 268 & 88 & 106 & 182 & 161 & 153 & 202 & 134 & 93 & 80 & 79 & 41 & 32 \\
\hline
\end{tabular}




\begin{tabular}{|c|c|c|c|c|c|c|c|c|c|c|c|c|c|c|c|}
\hline Netherlands & 653 & 212 & 102 & 69 & 89 & 141 & 48 & 91 & 17 & 186 & 52 & 24 & 53 & 14 & 36 \\
\hline France & 419 & 187 & 84 & 77 & 109 & 116 & 27 & 53 & 20 & 68 & 97 & 18 & 57 & 37 & 32 \\
\hline Spain & 890 & 283 & 192 & 83 & 50 & 154 & 83 & 137 & 77 & 129 & 79 & 177 & 59 & 30 & 16 \\
\hline Denmark & 267 & 105 & 60 & 50 & 73 & 77 & 23 & 43 & 7 & 41 & 31 & 6 & 78 & 20 & 22 \\
\hline Italy & 388 & 188 & 72 & 95 & 93 & 103 & 18 & 55 & 18 & 75 & 59 & 27 & 68 & 60 & 27 \\
\hline Norway & 185 & 80 & 46 & 48 & 74 & 46 & 14 & 32 & 10 & 40 & 29 & 9 & 15 & 17 & 59 \\
\hline
\end{tabular}


Table V

Ranking of the 30 Most Influential Universities in Marketing B2B.

\begin{tabular}{rlrrrrrr}
\hline R & Name university & H & TP & TC & TC/TP & ARWU & QS \\
\hline 1 & Michigan State University & 24 & 70 & 2366 & 33,80 & $101-150$ & 149 \\
2 & Georgia State University & 20 & 93 & 1846 & 19,85 & - & $751-800$ \\
3 & University of Manchester & 20 & 88 & 1194 & 13,57 & 38 & 34 \\
4 & Emory University & 19 & 27 & 1166 & 43,19 & $101-150$ & 147 \\
5 & University of New South Wales & 17 & 36 & 1244 & 34,56 & $101-150$ & 45 \\
6 & Lancaster University & 16 & 63 & 835 & 13,25 & $301-400$ & 135 \\
7 & University of North Carolina & 16 & 59 & 929 & 15,75 & 33 & 80 \\
8 & Penn State University & 16 & 48 & 1125 & 23,44 & 85 & -93 \\
9 & University of Bath & 16 & 36 & 843 & 23,42 & - & 160 \\
10 & Erasmus University Rotterdam & 16 & 33 & 802 & 24,30 & 73 & 147 \\
11 & University of Miami & 16 & 30 & 776 & 25,87 & $151-200$ & 252 \\
12 & University of Tennessee Knoxville & 16 & 25 & 838 & 33,52 & $201-300$ & $451-460$ \\
13 & Cranfield University & 15 & 36 & 991 & 27,53 & - & - \\
14 & Helsinki Sch Econ & 15 & 29 & 708 & 24,41 & - & - \\
15 & Temple University & 14 & 39 & 779 & 19,97 & $301-400$ & $651-700$ \\
16 & City University of Hong Kong & 14 & 36 & 411 & 11,42 & $201-300$ & 49 \\
17 & Stockholm School of Economics & 14 & 33 & 1209 & 36,64 & $401-500$ & - \\
18 & Florida State University & 14 & 33 & 882 & 26,73 & $201-300$ & $431-440$ \\
19 & Copenhagen Business School & 14 & 31 & 986 & 31,81 & - & - \\
20 & University of Minnesota Twin Cities & 14 & 23 & 884 & 38,43 & 34 & 163 \\
21 & McMaster University & 14 & 23 & 589 & 25,61 & 66 & 140 \\
22 & University of Mannheim & 14 & 18 & 1008 & 56,00 & - & 388 \\
23 & Aalto University & 13 & 51 & 807 & 15,82 & $401-500$ & 137 \\
24 & University of Warwick & 13 & 38 & 476 & 12,53 & $101-150$ & 57 \\
25 & University of Houston & 13 & 22 & 512 & 23,27 & $201-300$ & $601-650$ \\
26 & University of Pennsylvania & 13 & 21 & 795 & 37,86 & 17 & 19 \\
27 & Cardiff University & 12 & 32 & 461 & 14,41 & 99 & 137 \\
28 & University of Leeds & 12 & 30 & 452 & 15,07 & $101-150$ & 101 \\
29 & Uppsala University & 12 & 28 & 959 & 34,25 & 63 & 112 \\
30 & Bocconi University & 12 & 25 & 378 & 15,12 & - & - \\
\hline & & & & & &
\end{tabular}

Abbreviations: $\mathrm{R}=$ Rank; $\mathrm{TP}=$ Total publications; $\% \mathrm{TP} / \mathrm{Total}=$ Percentage of publications of the total in art; $\mathrm{TC}=$ Total citations; $\mathrm{TC} / \mathrm{TP}=$ Citations per paper, $\mathrm{H}=\mathrm{H}$-index . 
Table VI

Evolution in Five-Year Periods in the most influential universities for the period between 1990 and 2009.

\begin{tabular}{|c|c|c|c|c|c|c|c|c|c|c|c|c|c|c|c|c|c|c|c|c|}
\hline & $1990-1994$ & & & & & 1995-1999 & & & & & 2000-2004 & & & & & 2005-2009 & & & & \\
\hline $\mathrm{R}$ & University Name & TP & TC & $\mathrm{TC} / \mathrm{TP}$ & $\mathrm{H}$ & University name & TP & TC & TC/TP & $\mathrm{H}$ & University name & TP & $\mathrm{TC}$ & $\mathrm{TC} / \mathrm{TP}$ & $\mathrm{H}$ & University name & TP & TC & TC/TP & $\mathrm{H}$ \\
\hline 1 & Michigan State University & 7 & 86 & 12,29 & 5 & $\begin{array}{l}\text { University of North } \\
\text { Carolina }\end{array}$ & 9 & 168 & 18,67 & 6 & Michigan State University & 13 & 1071 & 82,38 & 12 & $\begin{array}{l}\text { Michigan State } \\
\text { University }\end{array}$ & 22 & 626 & 28,45 & 15 \\
\hline 2 & University of Pennsylvania & 6 & 248 & 41,33 & 6 & Michigan State University & 8 & 546 & 68,25 & 8 & Georgia State University & 12 & 781 & 65,08 & 10 & $\begin{array}{l}\text { University of } \\
\text { Manchester }\end{array}$ & 20 & 459 & 22,95 & 13 \\
\hline 3 & University of North Carolina & 6 & 37 & 6,17 & 4 & Baylor University & 8 & 84 & 10,50 & 6 & $\begin{array}{l}\text { University of Minnesota } \\
\text { Twin Cities }\end{array}$ & 10 & 576 & 57,60 & 9 & Georgia State University & 19 & 335 & 17,63 & 8 \\
\hline 4 & Jacksonville State Univ & 6 & 34 & 5,67 & 3 & University of Quebec & 7 & 136 & 19,43 & 6 & Temple University & 10 & 550 & 55,00 & 9 & Temple University & 17 & 195 & 11,47 & 10 \\
\hline 5 & McMaster University & 5 & 135 & 27,00 & 4 & University of Montreal & 7 & 133 & 19,00 & 6 & Penn State University & 10 & 505 & 50,50 & 10 & $\begin{array}{l}\text { Erasmus University } \\
\text { Rotterdam }\end{array}$ & 16 & 545 & 34,06 & 13 \\
\hline 6 & $\begin{array}{l}\text { University of Toledo } \\
\text { University of North Carolina }\end{array}$ & 4 & 19 & 4,75 & 2 & Old Dominion University & 7 & 79 & 11,29 & 5 & $\begin{array}{l}\text { Emory University } \\
\text { University of Tennessee }\end{array}$ & 10 & 779 & 77,90 & 10 & $\begin{array}{l}\text { Bocconi University } \\
\text { University of North }\end{array}$ & 16 & 302 & 18,88 & 11 \\
\hline 7 & Charlotte & 4 & 20 & 5,00 & 3 & Georgia State University & 7 & 412 & 58,86 & 6 & Knoxville & 9 & 512 & 56,89 & 9 & Carolina & 15 & 214 & 14,27 & 9 \\
\hline 8 & $\begin{array}{l}\text { University of Massachusetts } \\
\text { Lowell }\end{array}$ & 4 & 40 & 10,00 & 3 & $\begin{array}{l}\text { University of Southern } \\
\text { California }\end{array}$ & 6 & 152 & 25,33 & 5 & $\begin{array}{l}\text { University of North } \\
\text { Carolina }\end{array}$ & 9 & 478 & 53,11 & 9 & $\begin{array}{l}\text { University of New } \\
\text { South Wales }\end{array}$ & 15 & 324 & 21,60 & 10 \\
\hline 9 & University of Manchester & 4 & 33 & 8,25 & 4 & University of Miami & 6 & 206 & 34,33 & 6 & University of Manchester & 9 & 257 & 28,56 & 7 & Helsinki Sch Econ & 15 & 418 & 27,87 & 12 \\
\hline 10 & University of Kentucky & 4 & 20 & 5,00 & 3 & McMaster University & 6 & 221 & 36,83 & 5 & University of Bath & 9 & 269 & 29,89 & 7 & University of Leeds & 13 & 276 & 21,23 & 9 \\
\hline 11 & U. of Hawaii Manoa & 4 & 19 & 4,75 & 3 & $\begin{array}{l}\text { Massachusetts Institute of } \\
\text { Technology Mit }\end{array}$ & 6 & 236 & 39,33 & 6 & Colorado State University & 9 & 184 & 20,44 & 7 & Monash University & 13 & 255 & 19,62 & 9 \\
\hline 12 & University of Central Florida & 4 & 39 & 9,75 & 3 & University of Warwick & 5 & 136 & 27,20 & 5 & University of Miami & 8 & 332 & 41,50 & 6 & Cranfield University & 13 & 333 & 25,62 & 10 \\
\hline 13 & San Diego State University & 4 & 41 & 10,25 & 2 & Penn State University & 5 & 165 & 33,00 & 5 & Ohio State University & 8 & 887 & 110,88 & 7 & University of Bath & 12 & 248 & 20,67 & 8 \\
\hline 14 & Penn State University & 4 & 163 & 40,75 & 3 & U. of Wisconsin Madison & 4 & 202 & 50,50 & 4 & Florida State University & 8 & 521 & 65,13 & 7 & Lancaster University & 12 & 300 & 25,00 & 10 \\
\hline 15 & Harvard University & 4 & 87 & 21,75 & 3 & Texas Christian University & 4 & 440 & 110,00 & 4 & $\begin{array}{l}\text { Copenhagen Business } \\
\text { School }\end{array}$ & 8 & 758 & 94,75 & 8 & Emlyon Business School & 12 & 305 & 25,42 & 11 \\
\hline 16 & Florida Atlantic University & 4 & 28 & 7,00 & 3 & Purdue University & 4 & 184 & 46,00 & 4 & University of Notre Dame & 7 & 210 & 30,00 & 4 & Yonsei University & 11 & 210 & 19,09 & 9 \\
\hline 17 & Drexel University & 4 & 16 & 4,00 & 2 & $\begin{array}{l}\text { Karlsruhe Institute of } \\
\text { Technology }\end{array}$ & 4 & 161 & 40,25 & 4 & U. of Mannheim & 7 & 581 & 83,00 & 7 & $\begin{array}{l}\text { Eindhoven U. of } \\
\text { Technology }\end{array}$ & 11 & 314 & 28,55 & 7 \\
\hline 18 & Bryant Coll & 4 & 50 & 12,50 & 3 & Iowa State University & 4 & 50 & 12,50 & 3 & $\begin{array}{l}\text { University of Illinois } \\
\text { Urbana Champaign }\end{array}$ & 7 & 283 & 40,43 & 6 & $\begin{array}{l}\text { University of Warwick } \\
\text { University of Southern }\end{array}$ & 10 & 112 & 11,20 & 6 \\
\hline 19 & Baruch College Cuny & 4 & 9 & 2,25 & 2 & $\begin{array}{l}\text { Florida State University } \\
\text { Cleveland State }\end{array}$ & 4 & 83 & 20,75 & 4 & University of Strathclyde & 6 & 144 & 24,00 & 6 & $\begin{array}{l}\text { Denmark } \\
\text { Stockholm School of }\end{array}$ & 10 & 114 & 11,40 & 6 \\
\hline 20 & Wilfrid Laurier University & 3 & 33 & 11,00 & 2 & U.University & 4 & 45 & 11,25 & 4 & University of Pennsylvania & 6 & 375 & 62,50 & 6 & Economics & 10 & 279 & 27,90 & 10 \\
\hline
\end{tabular}


Page 20 of 25 
Table VII

Evolution in three-year periods of the most influential universities for the period between 2010 and 2015.

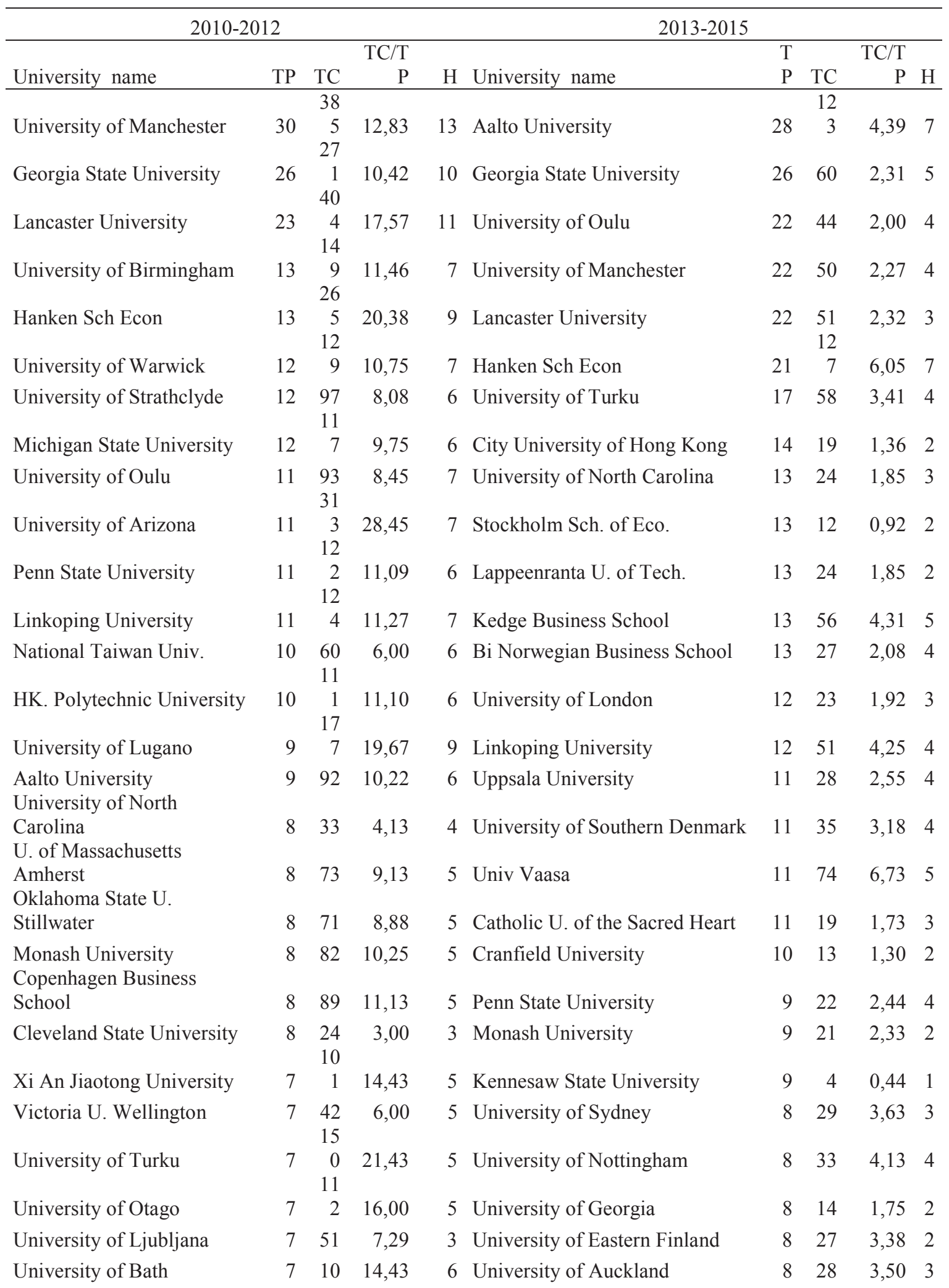


1

\begin{tabular}{llllllllll} 
Texas Tech University & 7 & 20 & 2,86 & 3 & Newcastle University Uk & 8 & 21 & 2,63 & 4 \\
Radboud U. Nijmegen & 7 & 48 & 6,86 & 4 & Michigan State University & 8 & 15 & 1,88 & 2 \\
\hline
\end{tabular}

Abbreviations: $\mathrm{TP}=$ Total publications; $\% \mathrm{TP} /$ Total $=$ Percentage of publications of the total in art; $\mathrm{TC}=\mathrm{Total}$ citations; $\mathrm{TC} / \mathrm{TP}=\mathrm{Citations}$ per paper 
Table VIII

Who cites in the most influential universities in Marketing B2B.

\begin{tabular}{|c|c|c|c|c|c|c|c|c|c|c|c|c|c|c|c|c|}
\hline $\begin{array}{l}8 \\
9 \\
10\end{array}$ & University & $\begin{array}{c}\text { Geor } \\
\text { gia } \\
\text { State } \\
\text { U. }\end{array}$ & $\begin{array}{c}\text { U. of } \\
\text { Manchester }\end{array}$ & $\begin{array}{c}\text { Michigan } \\
\text { State U. }\end{array}$ & $\begin{array}{c}\text { Lancaster } \\
\text { U. }\end{array}$ & $\begin{array}{c}\text { U. of } \\
\text { North } \\
\text { Carolina }\end{array}$ & $\begin{array}{l}\text { Aalto } \\
\text { U. }\end{array}$ & $\begin{array}{c}\text { Penn } \\
\text { State } \\
\text { U. }\end{array}$ & $\begin{array}{c}\text { Temple } \\
\text { U. }\end{array}$ & $\begin{array}{c}\text { U. of } \\
\text { Warwick }\end{array}$ & $\begin{array}{l}\text { U. of } \\
\text { New } \\
\text { South } \\
\text { Wales }\end{array}$ & $\begin{array}{l}\text { U. of } \\
\text { Bath }\end{array}$ & $\begin{array}{l}\text { Cranfield } \\
\text { U. }\end{array}$ & $\begin{array}{c}\text { City U. of } \\
\text { Hong } \\
\text { Kong }\end{array}$ & $\begin{array}{c}\text { Monash } \\
\text { U. }\end{array}$ & $\begin{array}{c}\text { Hanken } \\
\text { Sch } \\
\text { Econ }\end{array}$ \\
\hline 11 & Georgia State U. & 79 & 11 & 22 & 7 & 10 & 3 & 17 & 6 & 4 & 14 & 5 & 3 & 1 & 1 & 0 \\
\hline 12 & U. of Manchester & 21 & 65 & 28 & 48 & 20 & 20 & 12 & 10 & 5 & 23 & 39 & 11 & 9 & 2 & 8 \\
\hline 13 & Michigan State U. & 25 & 9 & 56 & 2 & 26 & 4 & 18 & 7 & 0 & 17 & 5 & 16 & 4 & 4 & 0 \\
\hline 14 & Lancaster U. & 11 & 32 & 0 & 49 & 5 & 12 & 2 & 2 & 3 & 3 & 28 & 10 & 1 & 1 & 5 \\
\hline 15 & U. of North Carolina & 13 & 6 & 42 & 4 & 33 & 4 & 15 & 12 & 1 & 5 & 2 & 6 & 3 & 4 & 0 \\
\hline 16 & Aalto U. & 19 & 28 & 14 & 14 & 5 & 57 & 9 & 7 & 2 & 21 & 13 & 8 & 1 & 5 & 16 \\
\hline 17 & Penn State U. & 9 & 4 & 14 & 1 & 9 & 1 & 36 & 1 & 1 & 8 & 2 & 2 & 1 & 2 & 1 \\
\hline 18 & Temple University & 11 & 0 & 9 & 0 & 0 & 1 & 6 & 17 & 2 & 4 & 0 & 3 & 2 & 1 & 1 \\
\hline 19 & U.of Warwick & 10 & 10 & 0 & 5 & 1 & 3 & 2 & 7 & 12 & 3 & 4 & 7 & 0 & 0 & 2 \\
\hline 20 & U. of New South W. & 17 & 4 & 15 & 2 & 4 & 7 & 8 & 2 & 1 & 32 & 4 & 7 & 1 & 2 & 3 \\
\hline 21 & University Of Bath & 0 & 12 & 0 & 7 & 4 & 5 & 4 & 8 & 5 & 4 & 27 & 7 & 0 & 4 & 3 \\
\hline 22 & Cranfield University & 20 & 10 & 8 & 6 & 3 & 4 & 9 & 3 & 2 & 7 & 8 & 41 & 0 & 1 & 9 \\
\hline 23 & City U.of HK. & 8 & 0 & 23 & 4 & 5 & 0 & 15 & 4 & 1 & 7 & 0 & 0 & 38 & 3 & 2 \\
\hline 24 & Monash U. & 15 & 0 & 15 & 1 & 7 & 5 & 4 & 8 & 5 & 11 & 4 & 3 & 4 & 17 & 0 \\
\hline 25 & Hanken Sch Econ & 9 & 17 & 0 & 9 & 0 & 14 & 0 & 0 & 4 & 11 & 6 & 12 & 0 & 2 & 36 \\
\hline
\end{tabular}


Page 24 of 25

1
2

3

4

5

6

7

8

9

10

11

12

13

14

15

16

17

18

19

20

21

22

23

24

25

26

27

28

29

30

31

32

33

34

35

36

37

38

39

40

41

42

43

44

45

46

47

48

49

50

51

52

53

54

55

56

57

58

59

60
Figure 1

Bibliographic Coupling of Countries in relation to B2B Marketing between 1990 and 2015.

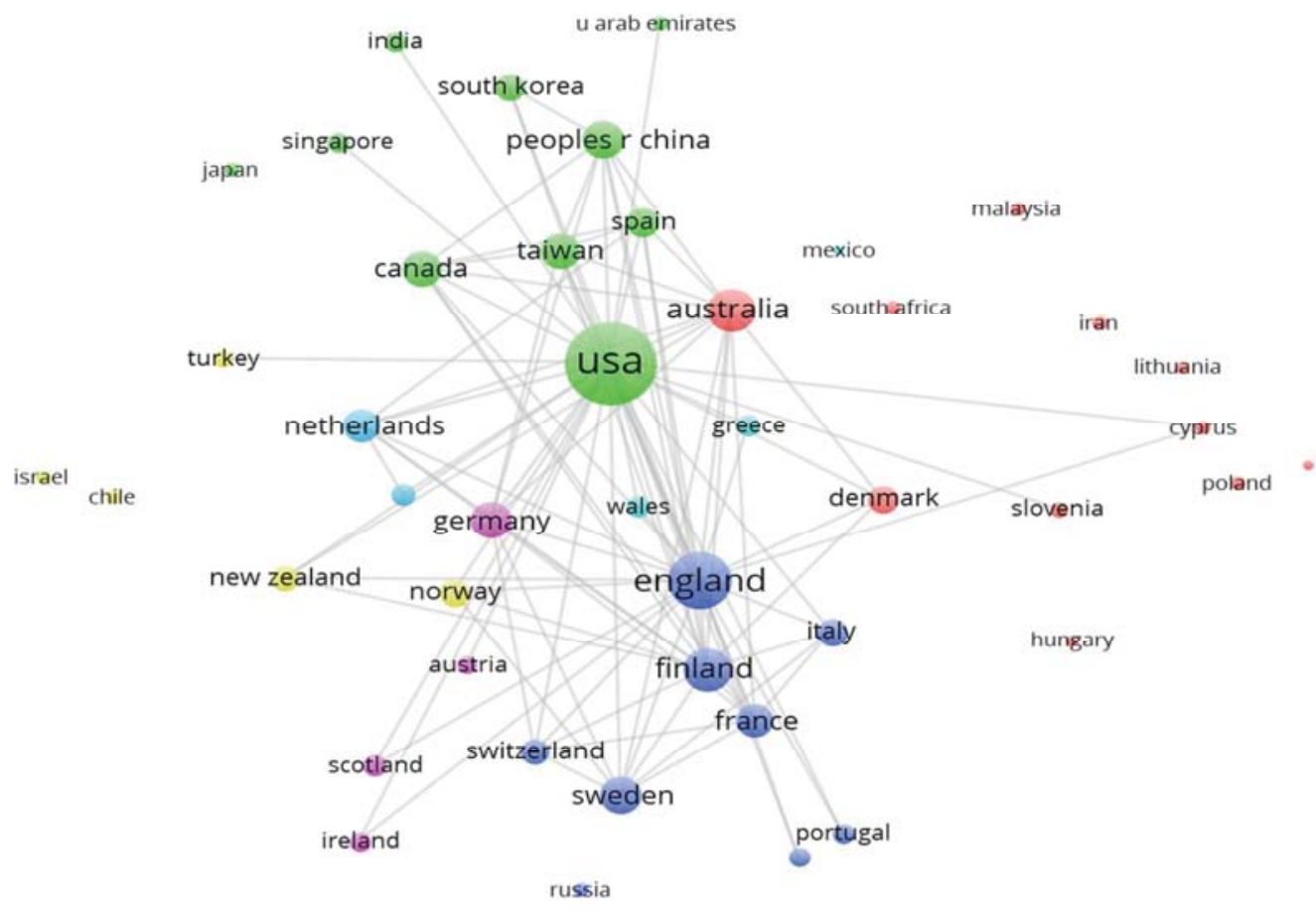




\section{Figure 2}

Bibliographic Coupling of Universities in relation to B2B Marketing between 1990 and 2015.

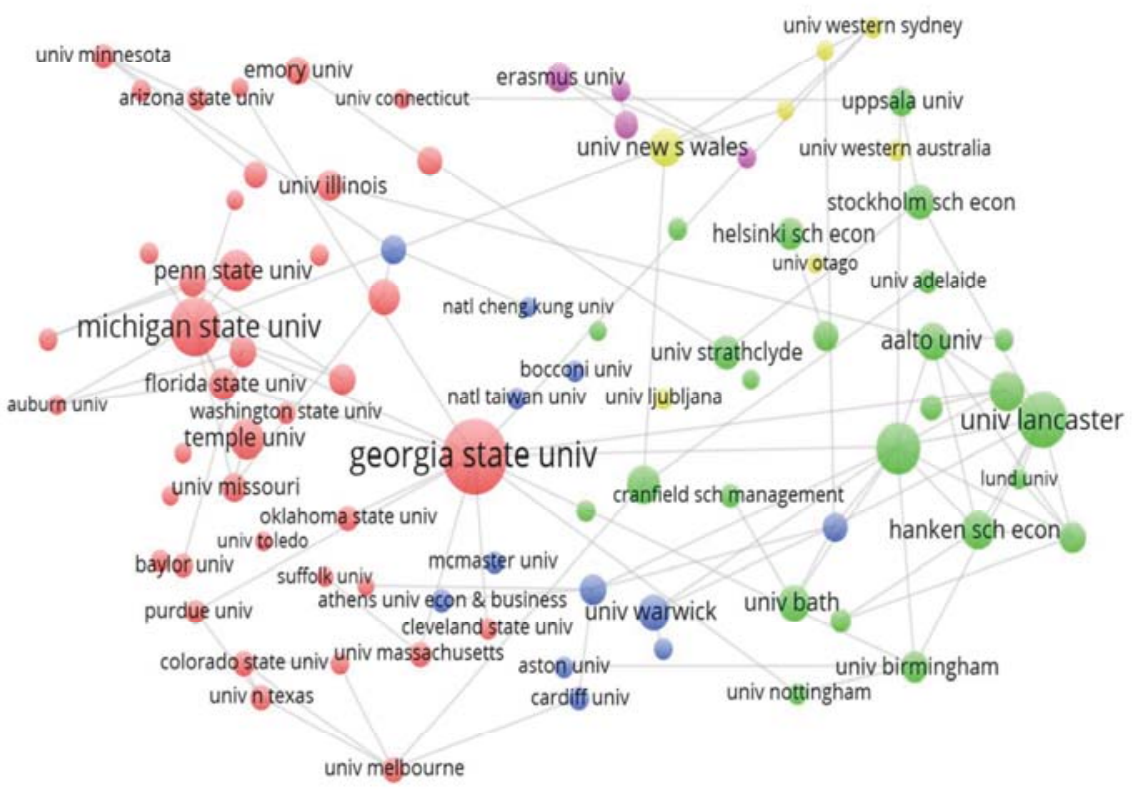

